\title{
Criteria and Constraints: the Human Rights Committee's Test on Limiting the Freedom of Religion or Belief
}

\author{
Gehan Gunatilleke \\ University of Oxford \\ gehan.gunatilleke@law.ox.ac.uk
}

\begin{abstract}
The Human Rights Committee - the treaty body established under the International Covenant on Civil and Political Rights_-performs a vital function in supervising the Covenant's implementation. This article presents an analytical account of the Committee's approach to determining the permissibility of limitations on the freedom of religion or belief under the Covenant. It finds that the Committee has set out certain primary legal criteria when determining the permissibility of a limitation. The Committee has then articulated certain additional normative constraints that apply to states' authority to limit rights — such as the requirement that the limitation be compatible with the principle of non-discrimination. Based on an analysis of the Committee's general comments and jurisprudence, the author argues that the Committee has offered a path towards imposing on states a heavier burden to justify limitations on the freedom of religion or belief.
\end{abstract}

\section{Keywords}

human rights - freedom of religion or belief - Human Rights Committee - limitation clauses - ICCPR

The freedom of religion or belief (FoRB) remains one of our most cherished and contested rights. International human rights law authorises states to limit elements of this right-specifically the freedom to manifest religion or belief. 
The legal contours of such authority can be found in specific international treaty provisions. The International Covenant on Civil and Political Rights $(\text { ICCPR })^{1}$ - the foremost international treaty that recognises FoRB - contains in article 18(3) a number of grounds on which the right may be limited. The Human Rights Committee - the treaty body that supervises the implementation of the ICCPR - plays an important role in guiding states on questions of limitations.

This article presents an analytical account of the Committee's work in determining the permissibility of limitations on FoRB under the ICCPR. It is presented in three sections. First, the article briefly recalls some of the key descriptive and conceptual features of FoRB that shape the way the right may be limited (section 2). The next section presents an interpreting article 18(3) of the ICCPR (section 3). It focuses specifically on the Human Rights Committee's General Comment on FoRB as an important source of interpretative guidance. According to the Committee, certain primary legal criteria and additional normative constraints shape the permissibility of any limitation on FoRB. The final section analyses the application of these criteria and constraints in the Committee's jurisprudence (section 4). This jurisprudence reveals that the Committee adopts two types of permissibility tests: a flexible test and rigorous test. ${ }^{2}$ The author goes on to argue that through its jurisprudence, the Committee has offered a path to imposing a more robust justificatory burden on states when they limit FoRB.

\section{$2 \quad$ Conceptualising FoRB}

The freedom to manifest religion or belief is occasionally conceptualised as a subset of the broader freedom of expression. ${ }^{3}$ This article avoids such a conceptualisation for two reasons. First, one might be sceptical about the claim that the two rights have the same normative roots. It is likely that this normative distinction has prompted the two rights to be traditionally distinguished from each other in international human rights law. The term "manifestation" is used exclusively in reference to religion or belief. This differentiation is

1 International Covenant on Civil and Political Rights (999 UNTS 171).

2 The author has examined UN archives as well as databases and has identified 83 cases that concern FoRB.

3 For useful discussions on this conceptualisation, see Paul M. Taylor, Freedom of Religion: UN and European Human Rights Law and Practice (Cambridge: Cambridge University Press 2005), p. 207; and Malcolm D. Evans, Religious Liberty and International Law in Europe (Cambridge: Cambridge University Press 1997), p. 285. 
occasionally defended through the claim that expressions of religion or belief require 'special status and special protection, different from the protection guaranteed to ordinary expression'.4 Second, there appears to be a linguistic distinction between the terms "manifest" and "express". Not all manifestations are definitively expressive in nature, such as when a person refuses vaccination owing to a religious conviction. Such instances certainly involve "manifestation"; but it is unclear as to whether they involve "expression" as well. Heiner Bielefeldt observes that the freedom to manifest religion or belief 'cannot be summed up under the heading of communicative freedom', as it could also include 'aspects of leading one's life in conformity with one's religion or belief', which do not necessarily involve contact with others. ${ }^{5}$ In any event, the debate over whether "manifestation" is a subset of "expression" is a domain of controversy this article will not enter.

Manfred Nowak describes the freedom to manifest religion or belief as often involving 'the communication of spiritual subject matter to the world at large and the defence of a conviction in public.' ${ }^{6}$ In international human rights law, FoRB is understood as covering 'worship, observance, practice and teaching', and may be exercised 'either individually or in community with others and in public or private. ${ }^{7}$

At a conceptual level, the freedom to manifest religion or belief is the external counterpart (forum externum) to the freedom to have or to adopt a religion or belief, which is understood as part of a person's 'inner realm of thinking and believing' (forum internum). ${ }^{8}$ This connection is important when it comes to limitations. The internal component of FoRB, i.e. the freedom to have or to adopt a religion of one's choice, is not subject to any limitations, and is 'unconditional' under article $18(2)$ of the Covenant. ${ }^{9}$ Yet the external component of FoRB, i.e. the freedom to manifest a religion or belief, is subject to limitations. Thus FoRB (along with the freedom of expression, which has a similar structure) occupies a unique and complex space in international human rights law. It is of paramount importance to the inherent dignity of persons; yet its manifestation may be legally restricted on certain grounds. Article 19 of the Covenant, which recognises the freedom of opinion and expression, has a

4 Taylor, supra note 3, p. 207; Evans, supra note 3, p. 285.

5 Human Rights Council, Report of the Special Rapporteur on freedom of religion or belief, Heiner Bielefeldt (A/HRC/28/66/Add.1), para. 7 .

6 Manfred Nowak, U.N. Covenant on Civil and Political Rights: Committee Commentary (Kehl am Rhein: NP Engel 2005), p. 411.

7 ICCPR, Art. 18(1).

8 A/HRC/28/66/Add.1, supra note 5, para. 7 .

9 Ibid. 
similar structure. As noted by Bielefeldt, " $[\mathrm{t}]$ his conceptual distinction appears nowhere else in the text of the Covenant'. ${ }^{10}$

\section{$3 \quad$ Interpreting Article 18(3)}

Article 18(3) of the ICCPR sets out the legal parameters of state authority to limit the freedom to manifest religion or belief. It provides that the right 'may be subject only to such limitations as are prescribed by law and are necessary to protect public safety, order, health, or morals or the fundamental rights and freedoms of others'. This section discusses two approaches to interpreting this provision: a plain reading, and a guided reading.

\subsection{A Plain Reading}

Article 31(1) of the Vienna Convention on the Law of Treaties (VCLT) ${ }^{11}$ sets out the basic rules on interpreting a provision of a treaty: 'A treaty shall be interpreted in good faith in accordance with the ordinary meaning to be given to the terms of the treaty in their context and in the light of its object and purpose.'

Article 31(2) meanwhile provides that "context" for the purpose of a treaty comprises inter alia the text of the treaty, and its preamble. The preamble of the ICCPR has several clauses worth recalling. First, the preamble recognises that the rights in the Covenant 'derive from the inherent dignity of the human person.'12 Second, it recognises 'the obligation of States under the Charter of the United Nations to promote universal respect for, and observance of, human rights and freedoms.'13 Third, it acknowledges that 'the individual, having duties to other individuals and to the community to which he belongs, is under a responsibility to strive for the promotion and observance of the rights recognised in the present Covenant. ${ }^{14}$ The three clauses appear to set out certain broad principles that underlie the Covenant: that rights derive from human dignity, that states have obligations to promote respect for and observance of 'human rights and freedoms', and that individuals have duties to others in terms of promoting and observing their rights. These principles taken together suggest that the drafters of the ICCPR would not have wished for states to limit rights without fulfilling a sufficiently heavy justificatory burden.

\footnotetext{
$10 \quad$ Ibid., para. 17.

11 Vienna Convention on the Law of Treaties (1155 UNTS 331), art. 32.

12 ICCPR, preamble.

13 Ibid.

14 Ibid.
} 
It seems untenable that those who believe that states are under a legal obligation to uphold certain rights should also believe that states could flippantly limit those rights. It is more sensible to think of limitations on rights as part of a state's obligations to uphold rights. This reading is also consistent with the notion that individuals who possess rights also have duties to uphold the rights of others. It seems plausible that limitations under the Covenant are extensions of the broader ambition of the drafters to impose obligations on states to uphold the rights of others. This overarching ambition, however, appears to be lost in the actual text of article 18(3), which offers a list of specific limitation grounds, i.e. the prescribed purposes for which a state is permitted to limit the right. The main challenge in interpretation relates to how vague and obscure these limitation grounds are.

The contested nature of limitation grounds is exemplified by the discussion that took place on the notion of "public order" among drafters of the Covenant. States observed that the English term "public order" differs significantly from the French term "l'ordre public". The English expression, found in common law countries, is ordinarily used to mean 'the absence of public disorder.' ${ }^{15}$ The French expression, used in civil law countries, is a legal concept that ordinarily concerns the negation of private agreements, the exercise of police powers, or the application of foreign law. ${ }^{16}$ This idea of "l'ordre public" would, in common law jurisdictions, be more akin to the notion of "public policy" than to "public order". ${ }^{17}$

The United Kingdom attempted to reconcile the divergent meanings attached to the words "public order" by suggesting the replacement of the phrase "protection of public order" with "prevention of public disorder". ${ }^{18}$ The revision would have effectively confined the meaning of the limitation ground to the common law idea of "preventing disorder". The United Kingdom urged that the words "ordre public" is tantamount to "public policy" in the English vocabulary, and that if 'public policy could be invoked to restrict freedom of religion, the restrictions could be stringent.19 ${ }^{19}$ France argued against this proposal, and observed that the 'the prevention of disorder' in French 'implied little more than police action to prevent street riots. ${ }^{20}$ 'Ordre public' by contrast has 'both

\footnotetext{
15 UN General Assembly, Draft International Covenants on Human Rights, 1oth Session (A/2929), p. 139.

16 Ibid.

17 Ibid.

18 Commission on Human Rights, Summary Record of the Three Hundred and Nineteenth Meeting, 8th Session, 17 June 1952 (E/CN.4/SR.319), p. 4.

19 Ibid., p. 12.

$20 \quad$ Ibid., pp. 4, 12.
} 
material and moral connotations and embrace[s] the whole of the principles on which the state was built.'. ${ }^{21}$ France suggested that the term 'ordre public' be retained in the French text, and that the phrase 'in the interests of ... [preventing] public disorder' be equated to 'ordre public'. States, including the Soviet Union, supported this broader limitation. The United Kingdom's proposal was eventually rejected by eight votes to seven, with three abstentions. ${ }^{22}$

If limitation grounds are ambiguous or obscure, they remain open to the interpretation of states. States are then likely to give themselves maximum leeway in such interpretation. For example, if the term "public order" can either mean the "absence of disorder" in the narrower sense, or "public policy" in the broader sense, it is likely that states will select the broader sense of the term. The state seeking to invoke "public order" as the justification for limiting FoRB would then only need to assert that the limitation serves some major public policy purpose. In fact, John Humphrey describes this ground as highly dangerous' precisely due to such inordinate breath. ${ }^{23}$

Meanwhile, the concept of "morals" is even more obscure than other limitation grounds. States that rely on this ground to justify a limitation would have near carte blanche over what constitutes "morals", and when a limitation on the grounds of "morals" is justified. The requirement that the state demonstrates the necessity of the limitation on the grounds of morals may become easily surmountable, as the state could define what the limitation is necessary for.

A plain or literal reading of article 18(3) does not appear to offer much clarity on the scope of state authority to limit FoRB. In the absence of such clarity, a broad margin of discretion is effectively afforded to states to determine such scope. Discretion of this nature fundamentally lightens the burden on states to justify a limitation on FoRB.

\section{2 $\quad$ A Guided Reading}

The work of the Human Rights Committee is a vital source of guidance on how to interpret article 18(3) in good faith, in its proper context, and in light

\footnotetext{
$21 \quad$ Ibid.

22 Ibid., p. 14.

23 John Humphrey, 'Political and Related Rights', in Theodor Meron (ed.), Human Rights in International Law: Legal and Policy Issues (Oxford: Oxford University Press, 1986), p. 185. See also John Humphrey, 'The Just Requirements of Morality, Public Order and the General Welfare in a Democratic Society', in R.S.J. MacDonald \& John Humphrey (eds.), The Practice of Freedom: Canadian Essays on Human Rights and Fundamental Freedoms (Toronto: Butterworth \& Co., 1979), pp. 146-147.
} 
of the ICCPR's object and purpose. ${ }^{24}$ Article 4O(4) of the ICCPR mandates the Committee to transmit 'general comments' to states parties. According to Michael O'Flaherty, general comments 'constitute authoritative legal analysis of the provisions of the treaty, except to the extent that the text might indicate otherwise. ${ }^{25}$ He clarifies that, where the comments appear to deviate from the text of a provision, they would 'constitute no more than policy-level suggestions.' ${ }^{26}$ The Committee itself has opined that the purpose of general comments is to promote the implementation of the Covenant, and 'to stimulate the activities of these States and international organisations in the promotion and protection of human rights. ${ }^{27}$

General Comment No. 22 of 1993 deals with the freedom of thought, conscience and religion including the freedom to manifest religion or belief. ${ }^{28}$ It reaffirms that article 18 'does not permit any limitations whatsoever on the freedom of thought and conscience or on the freedom to have or adopt a religion or belief of one's choice. ${ }^{29}$ By contrast, the freedom to manifest religion or belief is subject to limitations under the Covenant.

The Committee's general comment offers guidance on the interpretation of three specific aspects of article 18(3): first, on the definitions of limitation grounds; second, on the primary criteria for determining the permissibility of a limitation; and third on certain additional normative constraints that may be imposed on states when they limit FoRB.

\subsubsection{Defining Limitation Grounds}

The text of the Covenant offers little clarity on the precise definitions of the limitation grounds contained in article 18(3). Thus sources of guidance such

24 The 1985 Siracusa Principles on the Limitation and Derogation Provisions in the ICCPR is one such source of guidance. See Commission on Human Rights, Siracusa Principles on the Limitation and Derogation Provisions in the International Covenant on Civil and Political Rights (E/CN.4/1985/4, Annex).

25 Michael O'Flaherty, 'Freedom of Expression: Article 19 of the International Covenant on Civil and Political Rights and the Human Rights Committee's General Comment No. 34', 12:4 Human Rights Law Review (2012), p. 644. See also Human Rights Committee, Summary Record of the 2674th Meeting, (CCPR/C/SR.2674), para. 2.

26 O'Flaherty, supra note 25, p. 644.

27 Human Rights Committee, Report of the Human Rights Committee, Official Records of the General Assembly, Thirty sixth Session, Supplement No. 40, (A/36/40), annex VII, introduction; Human Rights Committee, General Comments Adopted by the Human Rights Committee under Article 40, paragraph 4, of the International Covenant on Civil and Political Rights, (CCPR/C/21/Rev.1.).

28 Human Rights Committee, General Comment No. 22-Article 18 (Freedom of Thought, Conscience or Religion) (CCPR/C/21/Rev.1/Add.4) [General Comment No. 22].

29 Ibid., para. 3. 
as the Committee's general comments can contribute towards a better understanding of these limitation grounds. Unfortunately, General Comment No. 22 is mostly silent on the definitions of limitation grounds such as public order, ${ }^{30}$ public safety, public health, and the fundamental rights and freedoms of others. ${ }^{31}$

General Comment No. 22 does, however, clarify the scope of "morals" as a ground for limiting the freedom to manifest religion or belief. The Committee observes that 'the concept of morals derives from many social, philosophical and religious traditions; consequently, limitations on [the freedom to manifest religion or belief] for the purpose of protecting morals must be based on principles not deriving exclusively from a single tradition. ${ }^{32}$ This conception of morals suggests that states cannot rely on moral principles that derive from just one tradition. It excludes from the scope of this limitation ground any arbitrary ideas of morality that are not shared across many traditions.

\subsubsection{Primary Criteria}

Through its general comments, the Committee has elaborated on three primary criteria that ought to be fulfilled for a limitation on FoRB to be permissible. These criteria emerge from the text of article 18(3): they must be (i) provided by law; (ii) applied only for a purpose prescribed in the Covenant, i.e. one of the specific limitation grounds; and (iii) 'directly related and proportionate to the specific need on which they are predicated. ${ }^{33}$

The Committee has explained elsewhere that under the first criterion, "law" must be 'formulated with sufficient precision to enable an individual to regulate his or her conduct accordingly and it must be made accessible to the

$30 \quad$ The Siracusa Principles explain that "public order" (ordre public) may be defined as "the sum of rules which ensure the functioning of society or the set of fundamental principles on which society is founded'. See Siracusa Principles, supra note 24, clause A(22).

31 The Siracusa Principles define "public safety" as 'protection against danger to the safety of persons, to their life or physical integrity or serious damage to their property', and "public health" as 'a serious threat to the health of the population or individual members of the population'. They also state that "the rights and freedoms of others" extends beyond the rights and freedoms recognised in the Covenant. See Siracusa Principles, supra note 24, clauses $\mathrm{A}(33), \mathrm{A}(25)$, and $\mathrm{A}(35)$.

32 General Comment No. 22, supra note 28, para. 8. See also Elizabeth K. Cassidy, 'Restricting Rights? The Public Order and Public Morality Limitations on Free Speech and Religious Liberty in UN Human Rights Institutions', 13:1 The Review of Faith \& International Affairs (2015), pp. 9-10.

33 General Comment No. 22, supra note 28, para. 8. 
public. ${ }^{34}$ In terms of the second criterion, the Committee observes that the limitation grounds contained in article 18(3) are exhaustive. ${ }^{35}$ It clarifies that article $18(3)$ of the Covenant 'is to be strictly interpreted: restrictions are not allowed on grounds not specified there, even if they would be allowed as restrictions to other rights protected in the Covenant, such as national security'. ${ }^{36}$ With regard to the third criterion, the Committee in General Comment No. 27 observes that 'restrictive measures ... must be appropriate to achieve their protective function' and 'must be the least intrusive instrument amongst those which might achieve their protective function' ${ }^{37}$

The three primary criteria found in the text of article 18(3) form the foundation of the legal test to determine the permissibility of a limitation on FoRB. Yet the strict fulfilment of these criteria alone does not necessarily ensure that a sufficiently heavy justificatory burden is imposed on states that seek to limit FoRB. Even fairly precise laws, such as laws that are meant to prevent public disorder or the incitement of violence, can be problematic if applied uncritically. For example, certain types of public disorder laws are sometimes justified on the grounds that 'public peace has to be protected against actions by offended members of the public'. ${ }^{38}$ The application of such laws where there is a genuine threat of public disorder may be framed as "necessary". However, such situations may be quite complex, and the permissibility of the limitation may not be obvious even when the limitation is necessary to prevent disorder. For instance, the "disorder" may arise from unreasonable violent responses to religious manifestations such as proselytization, wearing religious attire, or displaying religious symbols, all of which may be entirely non-violent forms of religious manifestation. A good example of this sort of application is the restriction of the religious practices of Ahmadis in Pakistan on the grounds of avoiding backlash from the Sunni majority. ${ }^{39} \mathrm{~A}$ response to this problem may

34 See Human Rights Committee, General Comment No. 34-Article 19 (Freedoms of opinion and expression), (CCPR/C/GC/34) [General Comment No. 34], para. 24. See also Antoon De Baets, 'A Historian's View of the International Freedom of Expression Framework', 1:1 Secrecy and Society (2016), p. 8.

35 General Comment No. 22, supra note 28, para. 8.

36 Ibid.

37 Human Rights Committee, General Comment No. 27(67)-Freedom of movement (article 12) (CCPR/C/21/Rev.1/Add.9), paras. 14-15; General Comment No. 34, supra note 34, para. 34 .

38 Human Rights Council, Freedom of religion or belief: Report of the Special Rapporteur on freedom of religion or belief (A/HRC/40/58), para. $3^{2}$.

39 Zaheeruddin v. State, 1993, Supreme Court of Pakistan, scmr 1718. See also Amjad Mahmood Khan 'Pakistan's Anti-Blasphemy Laws and the Illegitimate use of the "Law, 
be the articulation of certain additional normative constraints on state authority to limit FoRB.

\subsubsection{Additional Constraints}

In addition to the three primary criteria, the Human Rights Committee has articulated certain additional normative constraints that may be placed on a state's authority to limit rights. Two types of constraints are discussed in the Committee's general comments.

The first constraint concerns the primacy of rights. The Committee stipulates that a limitation must not vitiate the right at stake. In General Comment No. 22, it opines that a limitation 'must not be applied in a manner that would vitiate the rights guaranteed in article 18 ' of the Covenant. ${ }^{40}$ This reference to "rights" concerns both the freedom to manifest religion or belief, and the unconditional freedoms contained in article 18. Thus no limitation may be imposed on the freedom to manifest religion or belief where it results in a further limitation on any other freedom guaranteed in article 18, such as the freedom of conscience or the freedom to have or to adopt a religion or belief. For example, a restriction on children wearing particular attire within primary school premises is a common type of limitation on the freedom to manifest religion. When such a limitation results in the denial of a basic need, such as primary education, to persons of a particular faith, it may also amount to coercion that would impair the freedom to have or to adopt a religion or belief of one's choice. ${ }^{41}$ In such cases, the limitation in question may be impermissible, as it vitiates the unconditional freedom to have or to adopt a religion or belief guaranteed under article 18(2) of the Covenant.

The second constraint relates to covenant compatibility. The Committee stipulates that a limitation must be compatible with all other Covenant rights. It articulates in General Comment No. 22 an interpretative approach whereby states parties 'should proceed from the need to protect the rights guaranteed under the Covenant, including the right to equality and non-discrimination' when 'interpreting the scope of permissible limitation clauses. ${ }^{42}$ This articulation suggests that article 18(3) must be read in line with the overarching aim of protecting Covenant rights. For example, the Committee explicitly states that a

Public Order, and Morality" Limitation on Constitutional Rights', 13:1 The Review of Faith \& International Affairs (2015), p. 19 .

$40 \quad$ General Comment No. 22, supra note 28, para. 8.

41 Ibid., para. 5. See ICCPR, Art.18(2).

42 General Comment No. 22, supra note 28, para. 8. 
limitation on the freedom to manifest religion or belief cannot be 'imposed for discriminatory purposes or applied in a discriminatory manner. 43 This principle of covenant compatibility could be extended to require that a limitation be compatible with a range of Covenant rights. For instance, it could constrain limitations on FoRB where such limitations are imposed in a cruel or degrading manner, which would undermine the freedom from such treatment, guaranteed in article 7 of the Covenant.

The principle of covenant compatibility also relates to the fundamental interpretative rule in international treaty law encapsulated in article 31 of the VCLT. According to the Committee, the object and purpose of the Covenant concern the creation of legally binding standards for the universal respect for, and observance of, human rights and freedoms. ${ }^{44}$ The normative constraint requiring covenant compatibility reflects the need to interpret limitations in light of this overarching object and purpose.

\section{The Jurisprudence of the Committee}

The 1966 Optional Protocol to the ICCPR affords the Human Rights Committee the competence to 'receive and consider communications' from individuals subject to the jurisdiction of states that are party to the Protocol. ${ }^{45}$ Such communications contain claims that the state party has violated an individual's rights set forth in the Covenant. The Committee then offers its "views" on the communication; thus it performs a "quasi-adjudicative" function as part of its role in monitoring the implementation of the Covenant. ${ }^{46}$ The legally binding nature or the transformative value of the Committee's views ought not to be overstated. Yet the Committee's views in individual cases remain important to

43 Ibid. Special Rapporteurs have similarly insisted that limitations cannot be enacted with a discriminatory intention or effect. For example, Special Rapporteur on Freedom of Religion or Belief Ahmed Shaheed lists non-discrimination as the fourth criterion that a limitation must fulfil to be deemed permissible. See A/HRC/40/58, supra note 38, para. 17 .

44 See Human Rights Committee, General Comment No. 24(52) - Issues relating to reservations made upon ratification or accession to the Covenant or the Optional Protocols thereto, or in relation to declarations under article 41 of the Covenant, (CCPR/C/21/Rev.1/Add.6), para. 7 .

45 Optional Protocol to the International Covenant on Civil and Political Rights (999 UNTS 171), Art. 1.

46 Andrew M. Robinson, 'Would International Adjudication Enhance Contextual Theories of Justice? Reflections on the UN Human Rights Committee, Lovelace, Ballantyne and Waldman', 39:2 Canadian Journal of Political Science (2006), p. 280. 
understanding how the Covenant's limitation regime on FoRB is interpreted and applied in practice.

The Committee through its jurisprudence appears to have adopted two versions of its test to determine the permissibility of a limitation. On the one hand, it has adopted a flexible test where the specific legal criteria are not always applied when reaching a conclusion. On the other hand, it has adopted a rigorous test where all criteria are systematically applied, and other normative constraints are considered.

\subsection{Flexible Test}

In a number of cases dealing with FoRB, the Committee has applied a flexible test in assessing the permissibility of a limitation. The Committee has preferred not to rigorously assess whether the limitation in question satisfies each of the three permissibility criteria. Two illustrative cases may be discussed in this regard: Bikramjit Singh v. France (2013), ${ }^{47}$ and Ross v. Canada (2000). ${ }^{48}$

In Bikramjit Singh, the author was prohibited from wearing a keski (a type of mini turban worn by Sikh boys) in a state school, and was eventually expelled for refusing to comply with the prohibition. ${ }^{49}$ The state cited a French statute that prohibited wearing clothing that conveyed a religious affiliation in a conspicuous manner in a public school. It justified the limitation on FoRB based on the 'constitutional principle of secularism (laïcité)', and related the restriction to the prescribed purposes of protecting 'the rights and freedoms of others' and 'public order and safety'. 50

The Committee applied a relatively flexible test on permissibility; it opined that the limitation in question needed to be necessary and proportionate to the end that is sought, 'as defined by the state party' ${ }^{51}$ It then recognised that the principle of secularism (laïcité) was itself a means by which a state

47 Bikramjit Singh v. France, 1 November 2012, Human Rights Committee, Communication No. $1852 / 2008$.

48 Ross v. Canada, 18 October 2000, Human Rights Committee, Communication No. 736/1997.

49 Bikramjit Singh v. France, supra note 47, para. 8.5. The Committee has dealt with similar limitations on the FoRB of the Sikh community in Ranjit Singh v. France, 22 July 2011, Human Rights Committee, Communication No. 1876/2009. In the earlier case of Karnel Singh Binder v. Canada, the Committee found no violation of FoRB where the author, a Sikh, was required to wear a hard hat for his own safety. See Karnel Singh Binder v. Canada, 9 November 1989, Human Rights Committee, Communication No. 208/186.

$50 \quad$ Ibid., para. 5.8 .

$51 \quad$ Ibid., para. 8.5. 
party may seek to protect the religious freedom of all its population. ${ }^{52}$ Thus the Committee did not require the state to cite one of the specific limitation grounds contained in article 18(3), but deferred to the state when it came to the scope of the purpose invoked as a justification for limiting the right. The Committee accepted without much elaboration the idea that secularism in fact related to the protection of the rights and freedoms of others, and to public order.

The Committee did, however, imply that secularism could not be a basis on its own for limiting FoRB. Secularism still needed to be a means through which an explicitly mentioned limitation ground in article 18(3) was served. The Committee found that the state party had not furnished compelling evidence that the author posed a threat to the rights and freedoms of other pupils or to public order at the school by wearing his keski. ${ }^{53}$ It also found that the penalty of expulsion was disproportionate. Thus, despite applying a relatively flexible test, the Committee reached the conclusion that a violation of FoRB had taken place.

In Ross, the author (a teacher) was subjected to disciplinary action by the School Board for the public expression of controversial religious views concerning the Jewish faith. The author complained that the decision violated his rights under article 18, and his freedom of expression. He argued that his actions outside class had no bearing on his teaching, and that in fact there were no Jewish students in his class. The state asserted that the limitation was justified under the limitation grounds set out in article 18(3): the protection of the rights of others, and the protection of morals. ${ }^{54}$ With regard to the first ground, it argued that the restriction was imposed on the author for 'the purposes of protecting the freedom of religion and expression and the right to equality of the Jewish community'.55 With regard to the second, it asserted that the restriction was 'necessary to protect ... Canadian values of respect for equality and diversity (public morals)'.56

The Committee applied a flexible test in this case insofar as the first criterion was concerned. It acknowledged that the provisions of the New Brunswick Human Rights Act that the state relied upon—which made the School Board

$52 \quad$ Ibid., para. 8.6. This view appears to be endorsed by scholars such as Dominic McGoldrick. See Dominic McGoldrick, 'A Defence of the Margin of Appreciation and an Argument for its Application by the Human Rights Committee', 65:1 International and Comparative Law Quarterly (2016), p. $5^{2}$.

53 Bikramjit Singh v. France, supra note 47, para. 8.7.

54 Ross v. Canada, supra note 48, para. 6.11.

55 Ibid.

$56 \quad$ Ibid., para. 6.12. 
vicariously liable for discriminatory actions of its employees-were vague in terms of justifying the disciplinary action against the author. ${ }^{57}$ Yet the Committee ultimately accepted the state's claim that the limitation was provided by law. It deferred to the findings of the Supreme Court, which considered the author's appeal and found the limitation to be lawful. ${ }^{58}$ The Committee then chose to consider only the first limitation ground cited by the state-i.e. the rights of others - and did not make any findings on the state's invocation of the limitation ground on morals. It found that there was no violation of article 18, as the author's freedom to manifest his religion or belief was subject to limitations on the basis of protecting the rights of others. ${ }^{59}$ The Committee opined that members of the Jewish community had 'a right to be protected from religious hatred' under article 20 of the Covenant. ${ }^{60}$ This view echoed the Committee's observation in General Comment No. 22 that 'no manifestation of religion or belief may amount to propaganda for war or advocacy of national, racial or religious hatred that constitutes incitement to discrimination, hostility or violence' ${ }^{6}$

The Committee's assessment in terms of the third criterion, i.e. the necessity of the limitation, was confined to the limitation on freedom of expression, as it opined that the issues under articles 18(3) and 19(3) were 'substantially the same. ${ }^{62}$ It noted that the removal of the author from a teaching position was necessary to protect 'the right and freedom of Jewish children to have a school system free from bias, prejudice and intolerance. ${ }^{63}$ Furthermore, it observed that the author was appointed to a non-teaching position after 'only a minimal period on leave without pay and that the restriction thus did not go any further than that which was necessary to achieve its protective functions'.64 Therefore, the Committee concluded that the limitations on both FoRB and the freedom of expression were justified.

These two cases illustrate the Committee's application of a flexible test to assess whether a particular limitation satisfies the Covenant's criteria. The Committee has often glossed over the specifics of the first and second criteria

\footnotetext{
$57 \quad$ Ibid., para. 11.3.

$58 \quad$ Ibid., para. 11.4 .

59 Ibid., para. 11.8.

6o Ibid., para. 11.5. See also Jeroen Temperman, Religious Hatred and International Law: The Prohibition of Incitement to Violence or Discrimination (Cambridge: Cambridge University Press, 2015), p. 100.

61 General Comment No. 22, supra note 28, para. 7.

62 Ross v. Canada, supra note 48, para. 11.8.

63 Ibid., para. 11.6.

64 Ibid.
} 
and has accepted the state's asserted grounds for limiting FoRB. It has instead paid greater attention to the third criterion, i.e. that the limitation must be necessary and proportionate.

\subsection{Rigorous Test}

The Committee's application of a rigorous legal test to assess the permissibility of a limitation is exemplified in the cases of Sister Immaculate Joseph et al. v. Sri Lanka (2005), ${ }^{65}$ Miriana Hebbadj v. France (2018), ${ }^{66}$ and Sonia Yaker v. France (2018). ${ }^{67}$ These three cases illustrate the Committee's application of a rigorous legal test to determine the permissibility of limitations on FoRB. In each case, the Committee carefully and systematically assessed whether the three primary criteria for the permissibility of a limitation were satisfied, and placed a heavier burden on the state party to justify the limitation in question. In the latter two cases, the Committee also considered additional normative constraints relating to the principle of non-discrimination.

In Sister Immaculate Joseph, the authors were denied permission to incorporate an institution with an ostensible aim of spreading knowledge about the Catholic religion. The Supreme Court of Sri Lanka struck down the incorporation bill submitted by the authors on the basis that the proposed institution impaired the constitutional protection afforded to Buddhism in Sri Lanka. ${ }^{68}$ The Committee applied a reasonably rigorous permissibility test in this case. It first observed that spreading knowledge about one's beliefs to others were aspects of an individual's manifestation of religion protected under the Covenant. ${ }^{69}$ It then considered the first criterion of the test and observed that the Court's determination amounted to a limitation imposed by law. However, the Committee found that the state had not satisfied the second criterion, as it offered no justification for the limitation on FoRB other than 'reliance on the reasons set out in the decision of the Supreme Court itself.' ${ }^{70}$ It opined that the state had also failed to satisfy the third criterion, i.e. that the limitation must be

65 Sister Immaculate Joseph and 8o Teaching Sisters of the Holy Cross of the Third Order of Saint Francis in Menzingen of Sri Lanka v. Sri Lanka, 21 October 2005, Human Rights Committee, Communication No. 1249/2004.

66 Miriana Hebbadj v. France, 17 July 2018, Human Rights Committee, Communication No. 2807/2016.

67 Sonia Yaker v. France, 17 July 2018, Human Rights Committee, Communication No. $2747 / 2016$.

68 Sister Immaculate Joseph and 8o Teaching Sisters of the Holy Cross of the Third Order of Saint Francis in Menzingen of Sri Lanka v. Sri Lanka, supra note 65, para. 2.3.

69 Ibid., para. 7.2.

$70 \quad$ Ibid., para. $7 \cdot 3$. 
necessary and proportionate. The Committee accordingly concluded that the state had violated the authors' FoRB.

The Committee has meanwhile shown some willingness in its jurisprudential practice to apply certain additional constraints on the authority of states to limit FoRB. This willingness has been largely confined to the domain of nondiscrimination. In the recent cases of Miriana Hebbadj and Sonia Yaker, which involved the French ban on the niqāb (a full-face veil), the Committee stated that, in order for a limitation to be permissible, it must be 'non-discriminatory', in addition to meeting the usual primary criteria. ${ }^{71}$ The state in both cases sought to justify the limitation on FoRB on the grounds of public order, and the principle of "living together", which was couched in terms of protecting the fundamental rights and freedoms of others. ${ }^{72}$ The majority of the Committee in both cases found that the ban was not necessary to protect public order, insofar as it is clearly disproportionate to the stated objective. ${ }^{73}$ The majority also found that the concept of "living together" is too vague, and that the state party had not identified 'any specific fundamental rights or freedoms of others that are affected by the fact that some people present in the public space have their face covered, including fully veiled women. ${ }^{74}$ The majority in both cases accordingly found that the ban violated the authors' FoRB, and amounted to 'intersectional discrimination based on gender and religion, in violation of article 26 of the Covenant. ${ }^{75}$

While in Miriana Hebbadj and Sonia Yaker the relevant additional constraint concerned the principle of non-discrimination, the Committee's views could potentially be extended beyond non-discrimination. It is possible to extend this approach to require compatibility with other rights recognised in the Covenant. For instance, in Raihon Hudoyberganova v. Uzbekistan, ${ }^{76}$ the Committee found that the author's exclusion from studies on account of her

71 Miriana Hebbadj v. France, supra note 66, para. 7.5; and Sonia Yaker v. France, supra note 67 , para. 8.5 .

72 "Living together" was defined by the French government as 'the observance of the minimum requirements of life in society'. See Miriana Hebbadj v. France, supra note 66, para. 5.7; and Sonia Yaker v. France, supra note 67, para. 7.7. See also S.A.S. v. France, 1 July 2014, European Court of Human Rights, Application No. 43835/11.

73 Miriana Hebbadj v. France, supra note 66, para. 7.8; and Sonia Yaker v. France, supra note 67 , para. 8.8 .

74 Miriana Hebbadj v. France, supra note 66, para. 7.10; and Sonia Yaker v. France, supra note 67, para. 8.10.

75 Miriana Hebbadj v. France, supra note 67, para. 7.17; and Sonia Yaker v. France, supra note 67 , para. 8.17 .

76 Raihon Hudoyberganova v. Uzbekistan, 5 November 2004, Human Rights Committee, Communication No. 931/200o. 
religious manifestation violated her right to be free from coercion in matters of religion. Thus the Committee applied an additional constraint on the state's authority to limit the freedom to manifest religion or belief: it must not amount to or facilitate a violation of the author's unconditional right to be free from coercion when having or adopting a religion of her choice.

These recent cases reflect an important development in the Committee's overall approach to determining the permissibility of limitations. They indicate that the Committee is willing to go beyond the text of article 18(3) and consider other treaty provisions to constrain the authority of states to limit FoRB. Accordingly, the weight attached to the limitation grounds in article 18(3) is counterbalanced by other rights considerations, such as the principle of non-discrimination. Such an adjudicative approach may be important to ensure that the state has a sufficiently heavy burden to justify a limitation on FoRB.

Four principal observations may be made with respect to the Committee's approach to determining the permissibility of limitations on FoRB under the ICCPR.

First, the Committee has, through its general comments, set out reasonably clear primary criteria and additional constraints to determine the permissibility of limitations on FoRB.

Second, the Committee's jurisprudence on FoRB does not reflect a consistent application of the primary criteria for the permissibility of limitations. In some cases, the Committee has adopted a flexible legal test on permissibility, whereby the first two criteria of the test are virtually glossed over. On numerous occasions, vague aims have been accepted as relating to or falling within one of the specific limitation grounds found in article 18(3) of the ICCPR. In effect, the Committee has often failed to strictly interrogate the relevance of the state's justification in question. The Committee's focus in these cases has tended to be on the third criterion in the test: whether the limitation is necessary and proportionate. In other cases, the Committee has adopted a rigorous test on permissibility, whereby all three criteria in the test have been robustly assessed.

Third, if one were to holistically characterise the Committee's approach to adjudicating limitations on FoRB, it appears that the Committee has adopted an outcome-oriented approach as opposed to a process-oriented approach. The Committee has tended to focus on arriving at a particular outcome in 
a given case, rather than strictly applying its legal test. It is perhaps for this reason that we find the Committee routinely focusing on the third criterion in its legal test on permissibility. By contrast, a more rigorous interrogation of the first two criteria could be expected if the Committee adopted a processoriented approach.

Because the Committee has focused on the outcome of cases, the rigour of its test has not been particularly determinative. Even in certain cases where a flexible test was applied, the Committee appears to be guided by some normative instinct that prioritises the right at stake. In such cases, the Committee appears to be intent on securing outcomes that are consistent with protecting FoRB. For instance, in Bikramjit Singh, the Committee upheld FoRB despite applying a flexible permissibility test.

It should also be noted that a rigorous permissibility test does not necessarily guarantee the imposition of a sufficiently heavy justificatory burden on states. While such a test compels the state to demonstrate the precise harm caused by the exercise of the right, it does not necessarily maintain the primacy of rights over the vague and obscure limitation grounds that are listed in article 18(3) of the ICCPR. In fact, a strict application of the primary criteria could still lead to an outcome where a particular limitation is justified. For instance, even under a rigorous test, a limitation on FoRB could be justified on the grounds of "public order", despite the vagueness of this limitation ground. Therefore, the Committee's adoption of a rigorous test, though desirable as a means of constraining state authority, would not necessarily impose a sufficiently heavy justificatory burden on states. However, by rigorously insisting that the state meets each of the primary criteria in justifying a limitation, the Committee can move in the right direction. Cases such as Sister Immaculate Joseph suggest that a rigorous permissibility test is one method through which the Committee can ensure that FoRB is protected from unjustified limitations.

Finally, the Committee's jurisprudence suggests a willingness to place certain additional normative constraints on states' authority to limit FoRB. These constraints appear to be based on the idea that limitations must be compatible with the "provisions, aims and objectives" of the Covenant. The Committee has in its recent jurisprudence considered the relevance of the principle of nondiscrimination and has found that limitations on FoRB that fail to comply with the principle are impermissible. This additional constraint has come to be part of the Committee's assessment of the permissibility of a limitation. Thus, even when a particular limitation facially satisfies the three primary criteria found in article 18(3), it can still be impermissible if it has a discriminatory purpose or is applied in a discriminatory manner. While the Committee's jurisprudence does not adequately reflect the full gamut of additional normative constraints 
referenced in its general comments, the application of such constraints has gained some traction in practice. This jurisprudential development is arguably the most promising indication of the Committee's willingness to impose a heavier justificatory burden on states that seek to limit one of the most important rights featured in the modern human rights canon: the freedom of religion or belief. 